\title{
Strategies to Enhance the Teaching Competence of University Teachers in English Major
}

\author{
https://doi.org/10.3991/ijet.v16i10.22753 \\ Yafang Xiang \\ Shaoyang University, Shaoyang, China \\ xiangyafangdswe@126.com
}

\begin{abstract}
This research aims to seek strategies to enhance the teaching competence of university teachers in English major, which is affected by various factors. Firstly, the teaching competence deficiencies of university teachers in English major were analyzed, and the connotations of this competence were summarized. On this basis, a novel measurement system was established for such competence. Then, analytical hierarchy process (AHP) method was combined with Shannon's information theory into an improved model to measure the said teaching competence. In addition, several strategies were summarized to improve the teaching competence of university teachers in English major. The research results provide a good guide for the teaching reform works of English major in higher educational schools.
\end{abstract}

Keywords - Teaching competence, English major, colleges, competence measurement, analysis of strategy

\section{Introduction}

As science and technology blossom in modern society, higher education is developing towards the direction of quality education, and artificial intelligent (AI) technologies have been extensively and deeply applied in the field of higher education [14]. As an important component of higher education, the English major in higher educational schools is crucial for the cultivation of English talents, especially in 21st century, the requirement for professional talents is becoming increasingly urgent, and the English major in these higher educational schools has become indispensable [5-7]. In order to improve the capability and level of English majors in colleges and universities, it is necessary to make sure that the university teachers in English major must have excellent teaching competence, and only by ensuring the competence of English teachers can we lay a solid foundation for cultivating senior English professionals [810]. Therefore, seeking strategies to enhance the teaching competence of university teachers in English major has now become a hot area for pedagogical research, and existing research results have provided good references for enhancing the teaching competence of university teachers in English major. For example, targeting at the new teaching standards of colleges and universities, Li conducted a research on the teaching reform of English major and the enhancement of teachers' teaching competence 
[11]. Based on TPACK, Zhang discussed the strategies and ways to enhance the teaching competence of university teachers in English major and provided a good reference for the said issue [12]. Zheng discussed the teaching reform and advancement of English majors in higher educational schools in the context of the "Internet +" era, and provided a valuable reference for strengthening the teaching competence of English major teachers in the new era [13]. Yao analyzed the enhancement of teaching competence of normal school English major students and discussed from several aspects including the building of curriculum system, the construction of teaching practice system, and the cultivation of teacher qualities, etc. [14]. Vattøy explored the relationship between teachers' beliefs in feedback exercises and students' selfregulation, self-efficacy and language skills during the teaching of foreign languages, which can be used as a reference for improving teachers' teaching competence [15]. Rus explored a novel teaching method in engineering English teaching, which has a positive significance for improving teachers' teaching competence [16].

Above research findings have certain effects on improving the teaching competence of university teachers in English major. However, considering the dynamic features of social development, the characteristics of contemporary social requirements, and the different talent cultivation goals of modern higher education, it is still of certain necessity to further discuss the existing research results, in especial, it's of important significance to create a set of appraisal systems and models to measure the teaching competence of university teachers in English major. To this end, this paper concludes and optimizes the existing research findings, establishes a novel system for measuring the said teaching competence combining with AHP and the Shannon Information Theory [17-20], and proposes an improved model for measuring the said competence, in the hopes of offering a useful evidence for enhancing the teaching competence of university teachers in English major. In this paper, the research content is organized into 5 chapters. The first chapter overviews the current situations of English teaching in higher educational schools, and introduces existing research findings concerning the teaching competence of English teachers; moreover, it points out the deficiencies with previous research and gives the research meanings of this paper. The second chapter discusses the concrete details of the deficient teaching competence of university teachers in English major. The third chapter analyzes the measurement system for the said competence from multiple perspectives, and constructs a corresponding measurement model. The fourth chapter explores the ways and methods to improve the said competence. The fifth chapter draws the conclusions.

\section{Deficiencies with the Teaching Competence of University Teachers in English Major}

\subsection{Inadequate basic professional ability}

Inadequate basic professional ability is a common manifestation of the deficient teaching competence of teachers in college English major, especially in English major of higher vocational colleges, and this might have multiple reasons, first, compared 
with science and engineering majors, language majors are generally in a weak position in higher education; the benefits brought by language majors to the schools are not comparable to those brought by science and engineering majors, therefore in discipline construction, higher educational schools generally lay insufficient emphasis on the development of language disciplines or majors, resulting in that the introduction of English teaching talents can hardly be implemented effectively in colleges and universities. Overall speaking, the teacher resource of English major faculty is relatively weak and insufficient, the phenomenon of temporary shortages happens from time to time, that is, older teachers lack of working enthusiasm as they approach their retirement, and younger teachers haven't cumulated enough experience yet. Second, the English major hasn't received enough basic investment from the schools, so it's difficult to create good communication and training opportunities for university teachers in English major, as a result, their professional ability cannot be trained systematically, and their comprehensively ability cannot be improved sustainably.

\subsection{Inadequate teaching reform and innovation ability}

For the advancement of higher education, teaching reform and innovation can act as the catalysts; however, a few factors can restrain it, and if we really want to enhancing the teaching reform and innovation ability of university teachers, careful considerations must be given to these factors. In the implementation process of current higher education, teaching reform and innovation is a weak link in the qualityoriented education. Since the formulation and improvement of management systems, the development of social requirements, and the implementation of higher education are all dynamic processes, the teaching reform and innovation of higher education can hardly be systematized, especially for language majors such as English major, it is very difficult to find the right direction for teaching reform and innovation, resulting in that when teachers are performing teaching reform and innovation, they are aimless and there's very few substantial content, therefore many teaching reform programs have become mere formality and end in empty talks. In this process, these teachers cannot obtain the results they want through teaching reform and innovation, over time, they have lost their enthusiasm for teaching reform and innovation, which in turn resulted in that the improvement effect of teaching reform and innovation is not obvious and sometimes it's even weakened.

\subsection{Inadequate social development integration ability}

For higher education, the ultimate goal is to cultivate senior English talents who are able to meet the demand of the society. Therefore, during English teaching process in higher educational schools, not only the software and hardware conditions of English education in schools are aspects that should be considered, the employability of the cultivated English professionals should also be taken into account. As a language-based major, English major usually tends to lay more emphasis on the practical training of talents, that is, the talent training needs to combine with the actual needs of the society, and there is a counterpart employment problem in the talent cultivation of 
English majors, that is, different professional fields want different English talents, which makes the college English major have to consider not only the relationships among schools, society and institutions, but also the relationships among English teaching, scientific research, and social industries. These relationships can form a good development process, which can enhance the teaching competence of English teachers, as well as provide important evidences for the cultivation of English talents. However, judging from the current implementation mode, the teaching of English majors still adopts the traditional mode mostly, which is inclined to the imparting of theoretical knowledge, while lacking the necessary practical exercises.

\subsection{Inadequate ability for sustainable development}

Many factors can affect the sustainable development of English majors, such as some English teachers do not pursue to deepen their professional qualities and meanwhile their professional qualities are relatively low; some schools' teaching management system is incomplete and they haven't yet formed a good reward and punishment mechanism for teachers, so the teachers lack the enthusiasm and interest for professional development and training; the faculty of English major has inadequate ability, it hasn't formed a systematic talent cultivation mechanism, and the loss rate of level-talent is relatively high; the teaching system of English major in higher educational schools is not sound enough, and the ability to construct excellent courses and update the teaching materials is adequate, etc. All these factors would affect the improvement of the overall quality of English teachers, especially factors such as the imperfect teaching system, incomplete incentive mechanism, incompetent faculty and unsystematic courses will have a negative impact on English teachers with relatively poor professional quality, their mentality of having no desire to make progress will become even worse, which would result in that they seriously lack of the ability for sustainable development. If English teachers do not have a strong ability for sustainable development, they can hardly catch up with the times or grasp the features of English major development, then their teaching competence would become incompetent, and it's difficult for them to cultivate qualified and high-level English professionals.

\subsection{Inadequate adaptability}

The current higher education is a modern education mode that has integrated intelligence factors. In particular, with the in-depth application of AI, computer science, IT, Internet, and VR, the teaching process of higher educational schools requires the English teachers to master intelligent teaching techniques and tools, understand the new teaching concept, modes, methods, content, and forms under the intelligent teaching mode. However, how to master the teaching ideas and content under the intelligent education mode is a systematic project that requires English teachers to carry out professional learning and exercises, and only in this way can they deeply involve into the intelligent education mode, teach the English courses in an intelligent way, and adapt to the diversified requirements of the modern intelligent education 
mode. Whereas, at present, colleges and universities haven't done enough in this aspect, although they have adopted a few intelligent tools to assist their English teaching, their work is not systematic and of low intelligent level, the English teachers haven't truly gone deep into it, and most of their works are mere formality, which resulted in inadequate teaching adaptability of English teachers.

\section{Measurement System and Model}

\subsection{Index selection principles}

This paper holds that, in order to obtain indices that are more practical, the selection of indices for measuring the teaching competence of university teachers in English major should follow these principles:

First, the scientific and reasonable principle, that is, the indices should have clear and definite scientific meanings, and be able to rationally reflect the intrinsic problems of the objects to be measured.

Second, the objective and authentic principle, that is, the indices should be selected based on objective actual conditions and can reflect the real measurement content.

Third, the systemic principle, that is, the indices should have certain logical connotations.

Fourth, the complete principle, that is, the indices should be able to comprehensively describe the multiple sides of the objects to be measured.

Fifth, the transformable principle, that is, the data of the indices should be easily obtained for calculation and analysis.

\subsection{Construction of the measurement system}

The teaching competence measurement system should be able to examine the comprehensive quality and competence of university teachers in English major. This paper holds that, the teaching competence of teachers not only refers to their competence in teaching English (such as listening, speaking, reading, writing), but also includes their competence in teaching preparation, professional knowledge application, English knowledge deepening, professional knowledge transformation, and English teaching communication, etc. Based on the above-mentioned index selection principles, this paper holds that, the proposed system should be established from five aspects, that is, the course teaching competence, classroom teaching performance, teaching planning and execution, teaching reform and innovation, and teaching results. Table 1 shows the specific structure and content of the teaching competence measurement system of university teachers in English major. 
Table 1. Teaching competence measurement system of university teachers in English major

\begin{tabular}{|c|c|c|}
\hline Target layer & Criterion layer & Index layer \\
\hline \multirow{33}{*}{$\begin{array}{l}\text { Teaching competence meas- } \\
\text { urement system of university } \\
\text { teachers in English major }\end{array}$} & \multirow{4}{*}{$\begin{array}{l}\text { Course teaching } \\
\text { competence }\end{array}$} & Solid professional knowledge foundation \\
\hline & & Academic exchange \\
\hline & & Professional field and vision expansion \\
\hline & & Hotspot teaching content capture \\
\hline & \multirow{7}{*}{$\begin{array}{l}\text { Classroom teach- } \\
\text { ing performance }\end{array}$} & Classroom atmosphere \\
\hline & & Interaction in teaching process \\
\hline & & Correct teaching attitude \\
\hline & & Teaching information feedback \\
\hline & & Student interest motivation \\
\hline & & Language expression in classroom teaching \\
\hline & & Teaching communication \\
\hline & \multirow{7}{*}{$\begin{array}{l}\text { Teaching planning } \\
\text { and execution }\end{array}$} & Reasonable syllabus \\
\hline & & Reasonable teaching scheme \\
\hline & & Complete knowledge points \\
\hline & & Highlighted key and difficult points \\
\hline & & Intelligent teaching tools application \\
\hline & & Modern teaching method application \\
\hline & & Completion of teaching tasks \\
\hline & \multirow{8}{*}{$\begin{array}{l}\text { Teaching reform } \\
\text { and innovation }\end{array}$} & Excellent course responsible/participation \\
\hline & & Number of new teaching materials compiled \\
\hline & & Advanced teaching reform programs responsible \\
\hline & & Advanced teaching reform papers published \\
\hline & & High-level international academic exchange participated \\
\hline & & Awards of teaching demonstration courses \\
\hline & & Awards of teaching reform programs and papers \\
\hline & & $\begin{array}{l}\text { Conversion rate between English teaching and scientific } \\
\text { research }\end{array}$ \\
\hline & \multirow{7}{*}{ Teaching results } & Pass ratio of talents cultivated \\
\hline & & Excellent ratio of talents cultivated \\
\hline & & Loss ratio of students \\
\hline & & Employment ratio of students \\
\hline & & Social satisfaction \\
\hline & & Awards received by students in high-level competitions \\
\hline & & $\begin{array}{l}\text { Number of times students have been shortlisted in high- } \\
\text { level competitions }\end{array}$ \\
\hline
\end{tabular}

\subsection{Weight analysis of measuring indices}

AHP method is a simplification method for solving complex system decisionmaking problems. It decomposes problems into hierarchies and constructs a hierarchical structure with corresponding relationships, then it compares and analyzes the relevant decision factors of the complex system in pairs, and establishes an importance degree sequence of these factors [21-23]. This quantitative decision-making method is simple and practical, therefore this paper adopted it to analyze the weights of the measuring indices of the teaching competence of university teachers. 
At first, based on the proposed measurement system, this paper establishes a judgement matrix A for measuring indices in a same hierarchy:

$$
A=\left\{a_{i j}\right\}_{n \times n}=\left[\begin{array}{cccc}
a_{11} & a_{12} & \cdots & a_{1 n} \\
a_{21} & a_{22} & \cdots & a_{2 n} \\
\vdots & \vdots & \cdots & \vdots \\
a_{n 1} & a_{n 2} & \cdots & a_{n n}
\end{array}\right], 1 \leq i, j \leq n
$$

where, aij represents the score of the importance degree of index $i$ with respect to index $j$ given by evaluation experts based on a 1-9 score scale, greater aij value indicates higher importance of index $i$ with respect to index $j$, and there are aij $=1 /$ aji, aij $=1$.

Then, $\mathrm{Wi}$, the $\mathrm{n}$-th root of judgement matrix $\mathrm{A}$, and $\lambda \max$, the largest eigenvalue, were obtained as:

$$
\left\{\begin{array}{l}
W_{i}=\sqrt[n]{\prod_{j=1}^{n} a_{i j}} \\
\lambda_{\max }=\sum_{i=1}^{n}(A \mathbf{W})_{i} / n w_{i}
\end{array}\right.
$$

where, wi represents the weight of index i, namely:

$$
w_{i}=\frac{W_{i}}{\sum_{j=1}^{n} W_{i}}
$$

Perform consistency check on judgement matrix A:

$$
\left\{\begin{array}{l}
C I=\frac{\lambda_{\max }-n}{n-1} \\
C R=\frac{C I}{R I}
\end{array}\right.
$$

where, $\mathrm{CI}$ is the index of consistency, $\mathrm{RI}$ is the index of random consistency, and $\mathrm{CR}$ is the consistency ratio.

If there is:

$$
C R<0.1
$$

It means judgement matrix A can pass the consistency check, and the weights of the indices obtained based on this matrix are effective. Otherwise, the judgment matrix needs to be reset to make it meet the consistency test requirements. 


\subsection{Information quantity calculation model of the measuring indices}

Suppose there are m objects to be measured, then the value of the j-th index of the i-th object is $V_{j}(i)=\left[v_{j}^{\min }(i), v_{j}^{\max }(i)\right], v_{j}^{\text {min }}(i) \leq v_{j}^{\max }(i)$. According to the established measurement system we can see that, the $j$-th index might be a qualitative or a quantitative index; if it is a qualitative index, then we can obtain the value of the index and the corresponding fuzzy membership function, as well as the value of the fuzzy membership $\theta\left(V_{j}(i)\right)$. Information axiom is one of the important theories in the axiomatic design theory [24-27]. According to the information axiom, the quantity of fuzzy information corresponding to this index is:

$$
I\left(V_{j}(i)\right)=\log _{2} e^{1-\theta\left(V_{j}(i)\right)}
$$

If the $\mathrm{j}$-th index is a qualitative index, we need to further analyze it based on the type of the index, if the $\mathrm{j}$-th index is a benefit-type index, then it's normalized as:

$$
\left\{\begin{array}{l}
U_{j}(i)=\left[u_{j}^{\min }(i), u_{j}^{\max }(i)\right] \\
u_{j}^{\min }(i)=\left(v_{j}^{\min }(i)-R_{j}^{\min }\right) /\left(R_{j}^{\max }-R_{j}^{\min }\right) \\
u_{j}^{\max }(i)=\left(v_{j}^{\max }(i)-R_{j}^{\min }\right) /\left(R_{j}^{\max }-R_{j}^{\min }\right) \\
u_{j}^{\min }(i) \leq u_{j}^{\max }(i)
\end{array}\right.
$$

where, $R_{j}^{\max }$ and $R_{j}^{\min }$ respectively represent the maximum and minimum of the $\mathrm{j}$ th index.

If the $\mathrm{j}$-th index is a cost-type index, then it's normalized as:

$$
\left\{\begin{array}{l}
U_{j}(i)=\left[u_{j}^{\min }(i), u_{j}^{\max }(i)\right] \\
u_{j}^{\min }(i)=\left(R_{j}^{\max }-v_{j}^{\max }(i)\right) /\left(R_{j}^{\max }-R_{j}^{\min }\right) \\
u_{j}^{\max }(i)=\left(R_{j}^{\max }-v_{j}^{\min }(i)\right) /\left(R_{j}^{\max }-R_{j}^{\min }\right) \\
u_{j}^{\min }(i) \leq u_{j}^{\max }(i)
\end{array}\right.
$$

Similarly, the quantity of fuzzy information corresponding to this index is:

$$
I\left(V_{j}(i)\right)=\log _{2} e^{1-\frac{u_{j}^{\min }(i)+u_{j}^{\max }(i)}{2}-\min \left(u_{j}^{\min }(i)\right)}
$$

In particular, when the value of the $\mathrm{j}$-th index is an accurate value, then there is:

$$
I\left(V_{j}(i)\right)=\log _{2} e^{1-\frac{U_{j}(i)-\min \left(U_{j}(i)\right)}{\max \left(U_{j}(i)\right)-\min \left(J_{j}(i)\right)}}
$$




\subsection{Implementation of the measurement model}

According to the connotation analysis of the teaching competence of university teachers in English major, a teaching competence measurement system can be constructed based on the index selection principles; then indices of different types can be normalized, and a fuzzy information quantity calculation model of the teaching competence indices can be constructed as well, so as to obtain the fuzzy information quantity of the corresponding indices. After that, based on the fuzzy information quantity of the indices of all hierarchies, the weights of each index can be considered, and the total fuzzy information quantity of all indices of the i-th object can be obtained as $I(V(i))_{\text {total }}$, that is:

$$
I(V(i))_{\text {total }}=\sum_{j=1}^{n}\left(w_{j} * I\left(V_{j}(i)\right)\right)
$$

If there is:

$$
I(V(k))_{\text {total }}=\max _{1 \leq i \leq m}\left(I(V(i))_{\text {total }}\right), 1 \leq k \leq m
$$

It means that teaching competence of the $\mathrm{k}$-th object is the best.

\section{$4 \quad$ Ways and Methods to Improve Teaching Competence}

\subsection{Increase basic input in English discipline and enhance the comprehensive professional ability of English teachers}

The comprehensive professional ability of university teachers is a crucial component of their teaching competence, and it is also the most basic manifestation of whether their teaching competence can meet the job requirements of English major. Thus, to improve their teaching competence, the first thing is to enhance their comprehensive professional ability; and, to enhance such ability, good software and hardware are also required to ensure the research and development of English major and to lay a concrete foundation for the enhancement of the comprehensive professional ability of university teachers. As a result, strengthen the ability of English major faculty is of very important significance. This paper holds that, to strengthen the competence of English major faculty, works of the following aspects should be done well, the first is to increase basic input in college English major to meet the requirements of the teaching of English courses and scientific research programs; the second is to introduce senior teaching talents and construct a competitive faculty and research team; the third is to construct infrastructures for English teaching and scientific research, so as to offer assistance to the successful implementation of teaching activities and research programs. 


\subsection{Improve the teaching management system and establish a long-term incentive mechanism for university teachers in English major}

A sound English major teaching management system provides a surety for the teaching of English courses, and it points out direction for formulating teaching plans and schemes, as well as for implementing teaching activities and realizing teaching tasks; moreover, it provides standards and a basis for the appraisal of teaching and learning outcomes of English courses. Therefore, formulating a sound English major teaching management system based on actual teaching practice in universities is an important condition for enhancing the teaching competence of university teachers. Under the guidance of such system, the teaching works will have a clear orientation and professional development background; also, the system can clarify the teaching goals and direction for university teachers in English major, which also has a positive role in formulating personal career development plans for university teachers in English major. This paper holds that, formulating a sound English major teaching management system requires to take multiple factors into consideration, such as the situations of the schools, the development conditions of teachers, the student sources, the managerial capabilities, and the development orientation of the English major, etc., so that the teaching management system can be more scientific, reasonable, and objective. In addition, establishing a long-term incentive mechanism for English teachers is also a key consideration when building the teaching management system, and it can stimulate the enthusiasm and innovativeness of university teachers.

\subsection{Promote industry-university-research cooperation mechanism and enhance the integration ability of university teachers}

The teaching competence of university teachers is not only reflected in the ability to impart the knowledge listed in the text books, but also the ability to combine all kinds of knowledge and have a profound understanding of the discipline. In the development process, modern higher education has attached more importance to the promotive relationships among the industries, the colleges and universities, and the scientific research, and it is making great efforts to promote the cooperative relationships among the three, so that they can form a virtuous cycle, and thereby promoting the teaching quality and teaching level of higher education. For higher education, English major is playing an indispensable role in cultivating senior language talents. Therefore, vigorously promoting the industry-university-research cooperation mechanism is an inevitable trend for English teaching. By introducing scientific research results and industrial development results in the development of English major, a good supplement could be provided for English courses; moreover, during the integration of course teaching and scientific research, new professional visions and development opportunities could be brought to the development of social industries, and thus forming a mutually complementary and mutually reinforcing cooperation mode. During the implementation of such cooperation mode, inevitably, it will require the teachers to have a solid industry-university-research integration ability, and only in this 
way can they keep up with the pace of the times and provide continuous vitality for the development of English teaching.

\subsection{Strengthen cooperation, exchanges and training to improve English teachers' sustainable development ability}

The sustainable development ability of English teachers is an important manifestation of their teaching competence. Per the requirement of the times, the teaching goals, schemes, content, planning, and tasks of English teaching must be adjusted in a timely manner, that is, the teaching of English courses is a dynamic development process; in this process, due to changes of various teaching factors and conditions, the teaching modes, concept, methods, forms must be changed accordingly. How could we adapt to such changes? Obviously, this requires English teachers to conduct selflearning continuously, enhance cooperation and exchanges with external partners and institutions, actively participate in training programs organized by schools or social organizations, and strengthen their sustainable development ability; only in this way can they well adapt to various changes in the teaching situations.

\subsection{Use intelligent technologies for modern education and enhance English teachers' adaptability}

As science and technology blossom in current society, various intelligent technologies have emerged, causing great changes in information transmission and communication forms. The traditional teaching mode can no longer adapt to the demand of higher education in modern days, many intelligent technologies have been integrated into higher education, and English teachers need to use these intelligent technologies to assist their teaching and enhance the teaching quality of English courses. In the meantime, during the teaching process, intelligent technologies can help with the preparation works of teaching activities by simulating and displaying teaching scenes of English courses, and they can also give timely feedback to the English teaching status and information, effectively formulate teaching schemes, and deepen the classroom practical ability of English teachers, and all these are quite helpful for teachers to master the progress of course teaching and improve their adaptability.

\subsection{Enhance teachers' concept of advancing with the times and improve their teaching reform and innovation ability}

Higher education has very obvious characteristics of the times, especially the modern higher education which aims to cultivating high-level talents, its talent cultivation goals must be tightly connected to the development features of the times. The $21 \mathrm{st}$ century is a new era that lays great emphasis on knowledge and talents, in the development process of this era, how to achieve high-efficient and high-quality training of senior professionals is an important research hotspot. To cultivate high-quality professional talents, special attention needs to be paid to the particularity of English major, and English teachers should be able to combine with the characteristics of the times to 
continuously improve their understanding for the cultivation of English professionals, and enhance their concept of advancing with the times during the course teaching, moreover, they also need to actively participate in teaching reform programs of English talent cultivation, and explore more advanced modes for the cultivation of English professional talents. At the same time, English teachers also need to give some attentions to teaching material compilation, curriculum construction, and teaching theory research, and these are also helpful to enhancing the teaching reform and innovation ability of English teachers, and offering aids for strengthening their teaching competence.

\section{Conclusion}

This paper studied a few issues with the teaching competence of university teachers and analyzed its essential problems and connotations. Based on the actual teaching practice of English major in colleges and universities, it constructed a system and model for measuring the teaching competence of university teachers with a few indices of different types, realizing quantitative analysis of such teaching competence. Moreover, this paper proposed a few strategies for enhancing the said competent, providing a good reference for enhancing the teaching competence of teachers of other language courses.

\section{Acknowledgment}

Fund by the Philosophy and Social Science Fund Project of Hunan Province in 2019 A Cultural Cognitive Study of Conceptual Metaphors of English Verbs (19WLH28).

\section{$7 \quad$ References}

[1] Yang, R. (2020). Artificial Intelligence-Based Strategies for Improving the Teaching Effect of Art Major Courses in Colleges, International Journal of Emerging Technologies in Learning, 15(22): 146-160. https://doi.org/10.1016/10.3991/ijet.v15i22.18199

[2] Cai, X., Garnova, N., Filippova, A., Glushkov, S. (2020). Intelligent automation of student performance assessment based on cloud services, International Journal of Emerging Technologies in Learning, 16(2): 149-158. https://doi.org/10.1016/10.3991/ijet.v16i02.18 $\underline{827}$

[3] Liu, L.M. (2020). Analysis on class participation based on artificial intelligence. Revue d'Intelligence Artificielle, 34(3): 369-375. https://doi.org/10.18280/ria.340316

[4] Zhao, Y.X., Ren, W., Li, Z. (2020). Prediction of English scores of college students based on multi-source data fusion and social behavior analysis. Revue d'Intelligence Artificielle, 34(4): 465-470. https://doi.org/10.18280/ria.340411

[5] Dimova, S. (2020). English language requirements for enrolment in EMI programs in higher education: A European case. Journal of English for Academic Purposes, 47: 1-13. https://doi.org/10.1016/j.jeap.2020.100896 
[6] Gao, X. (2020). Strategies for Reforming English Teaching Modes in Higher Vocational Colleges from Perspective of Professional Ability. Teaching of Forestry Region, (7), 8082. https://doi.org/10.3969/j.issn.1008-6714.2020.07.024

[7] Zhu, M. (2020). Research on the Education Model of College Students' English Application Ability Based on the OBE Education Idea. Journal of Hubei Open Vocational College, 33(18): 172-173+176. https://doi.org/ 10.3969/j.issn.2096-711X.2020.18.074

[8] Duran, D., Sert, O. (2019). Preference organization in English as a Medium of Instruction classrooms in a Turkish higher education setting. Linguistics and Education, 49: 72-85. https://doi.org/10.1016/j.linged.2018.12.006

[9] Shi, Y. (2020). On the Improvement of the Quality of English Teachers in Higher Vocational Colleges by the Teaching ability Competition of the National Vocational College Skills Competition. The Guide of Science \& Education, (24): 81-82. https://doi. org/10.16400/j.cnki.kjdkx.2020.08.037

[10] Pei, Y.Q. (2019). Research on the reform and development of College English teaching based on the Internet plus Era. Journalism Research Herald, 10(7): 13-14. https://doi.org/ $\underline{10.3969 / j . i s s n .1674-8883.2019 .07 .010}$

[11] Li, M. (2020). A Study of College English Teaching Reform and Improvement of Teaching ability. Science \& Technology Information, 18(21): 138-139+142. http://dx.doi. org/10.16661/j.cnki.1672-3791.2002-5599-6705

[12] Zhang, Y. (2020). A study on present situation and promotion strategies of university teachers in english major information-based teaching ability in private colleges under the background of TPACK. Journal of Jilin Agricultural Science and Technology College, 29(4): 30-33.

[13] Zheng, B.Q. (2018). Research on the reform and development of College English Teaching in the context of Internet plus. Course Education Research, 5(24): 78-79. https://doi.org/10. 16541/j.cnki.2095-8420.2018.24.032

[14] Yao, Y.S. (2020). Research on the improvement of teaching ability of English Majors in Higher Vocational Colleges. Journal of KaiFeng Vocational College of Culture \& Art, 40(7), 104-105. https://doi.org/ 10.3969/j.issn.2096-7853.2020.07.046

[15] Vattøy, K.D. (2020). Teachers' beliefs about feedback practice as related to student selfregulation, self-efficacy, and language skills in teaching English as a foreign language. Studies in Educational Evaluation, 64: 1-10. https://doi.org/10.1016/j.stueduc.2019.100828

[16] Rus, D. (2020). Creative Methodologies in Teaching English for Engineering Students. Procedia Manufacturing, 46: 337-343. https://doi.org/ 10.1016/j.promfg.2020.03.049.

[17] Yang, Z.H. (2020). Analysis of the impacts of open residential communities on road traffic based on AHP and fuzzy theory. Ingénierie des Systèmes d'Information, 25(2): 183-190. https://doi.org/10.18280/isi.250205

[18] Jorge-García, D., Estruch-Guitart, V. (2020). Economic valuation of ecosystem services by using the analytic hierarchy process and the analytic network process. comparative analysis between both methods in the Albufera Natural Park of València (Spain). International Journal of Design \& Nature and Ecodynamics, 15(1): 1-4. https://doi.org/10.18280/ ijdne. 150101

[19] Kundu, S. (2017). Derivation of Hunt equation for suspension distribution using Shannon entropy theory. Physica A: Statistical Mechanics and its Applications, 488: 96-111. https:// doi.org/10.1016/j.physa.2017.07.007

[20] Pratheepa, M., Verghese, A., Bheemanna, H. (2016). Shannon information theory a useful tool for detecting significant abiotic factors influencing the population dynamics of Helicoverpa armigera (Hübner) on cotton crop. Ecological Modelling, 337: 25-28. https://doi.org/10.1016/j.ecolmodel.2016.06.003

[21] Abrams, W., Ghoneim, E., Shew, R., LaMaskin, T., Al-Bloushi, K., Hussein, S., AbuBakr, M., Al-Mulla, E., Al-Awar, M., EI-Baz, F. (2018). Delineation of groundwater potential 
(GWP) in the northern United Arab Emirates and Oman using geospatial technologies in conjunction with Simple Additive Weight (SAW), Analytical Hierarchy Process (AHP), and Probabilistic Frequency Ratio (PFR) techniques. Journal of Arid Environments, 157: 77-96. https://doi.org/10.1016/j.jaridenv.2018.05.005

[22] Garg, C.P., Kashav, V. (2020). Assessment of Sustainable Initiatives in the Containerized Freight Railways of India using Fuzzy AHP Framework. Transportation Research Procedia, 48: 522-539. https://doi.org/10.1016/j.trpro.2020.08.057

[23] Mojaver, P., Khalilarya, S., Chitsaz, A., Assadi, M. (2020). Multi-objective optimization of a power generation system based SOFC using Taguchi/AHP/TOPSIS triple method. Sustainable Energy Technologies and Assessments, 38: 1-13. https://doi.org/10.1016/j. seta.2020.100674

[24] Pahlavani, P., Sheikhian, H., Bigdeli, B. (2017). Assessment of an air pollution monitoring network to generate urban air pollution maps using Shannon information index, fuzzy overlay, and Dempster-Shafer theory, A case study: Tehran, Iran. Atmospheric Environment, 167: 254-269. https://doi.org/10.1016/j.atmosenv.2017.08.039

[25] Rohm, K., Bonab, V.S., Manas-Zloczower, I. (2020). Quantitative evaluation of mixing using a refined Shannon entropy. Composites Science and Technology, 197: 1-8. https:// doi.org/10.1016/j.compscitech.2020.108276

[26] Roxani, K., Karagiannis, G. (2020). Constructing composite indicators with Shannon entropy: The case of Human Development Index. Socio-Economic Planning Sciences, 70: 1-14. https://doi.org/10.1016/j.seps.2019.03.007

[27] Hamidreza, S., Ashkan, H., Reza, F. (2018). Extending a pessimistic-optimistic fuzzy information axiom-based approach considering acceptable risk: Application in the selection of maintenance strategy. Applied Soft Computing, 67: 895-909. https://doi.org/ $\underline{10.1016 / j . a s o c .2017 .11 .017}$

\section{Author}

Yafang Xiang, was born on October 4, 1983 in Shaoyang County, Hunan Province, China. She is currently a lecturer in School of Foreign Languages, Shaoyang University. She graduated from Kunming University of Science and Technology, where she received a B. A degree in English Language and Literature in 2005. She received her M. A degree in Foreign Linguistics and Applied Linguistics from Central South University in 2008. Her M. A thesis is titled "A Study of Relationship among Motivation Orientations, Metacognitive Awareness and Proficiency in Chinese High School Students' English Listening". She has specialized in second language acquisition, cognitive linguistics and began her professional career as an English teacher in 2009. With more than 11 years' teaching experience she is mainly responsible for teaching "Basic English" course and "English Listening" course for English majors. She has hosted or mainly participated in two provincial-level research projects (including the Philosophy and Social Science Fund Project of Hunan Province in 2019 "A Cultural Cognitive Study of Conceptual Metaphors of English Verbs") and 4 municipal-level projects. In recent years, more than 10 academic papers have been published by her as the first author. Email: xiangyafangdswe@126.com.

Article submitted 2021-02-12. Resubmitted 2021-03-24. Final acceptance 2021-03-24. Final version published as submitted by the authors. 